Article

\title{
The Concept of Sustainable Strategy Implementation
}

\author{
Joanna Radomska \\ Received: 21 October 2015; Accepted: 19 November 2015; Published: 30 November 2015 \\ Academic Editor: Adam Jabłoński \\ Strategic Management Department, Wrocław University of Economics, ul. Komandorska 118/120, \\ 53-345 Wrocław, Poland; joanna.radomska@ue.wroc.pl; Tel.: +48-71-36-80-195
}

\begin{abstract}
The idea of sustainable development has been present in the field of management for many years, yet the challenges and rules of contemporary business mean that it remains topical. At the same time, the results of much research indicates an unsatisfactory level of execution of development concepts. Due to this, the subject of the study encompasses the implementation of the idea of sustainability in the strategy execution process, lending it a holistic and balanced nature. The purpose of the paper is an examination of the relationship between strategy implementation and the effectiveness of the strategy execution process. The relationships between the perspectives defined and results obtained by organizations were investigated. The research demonstrated the existence of a positive correlation of varied intensity. It is thus possible to identify a positive influence of the integration of the idea of sustainability with strategy execution, which is reflected in the effectiveness of activities undertaken.
\end{abstract}

Keywords: strategy execution; sustainability; strategic management process

\section{Introduction}

An increasing pressure to ensure productivity and effectiveness forces companies to improve their management systems, making them ever more complex. Confirmation of this trend is visible in the implementation of holistic management models which emphasize the need to concentrate on the high quality of the functionality of their components [1]. It is thus possible to find recommendations referring to the sustainable design of the strategic management process in the literature. Sustainability is defined as a concept of the holistic perspective of development integrated with organizational goals, internal incentives and evaluation systems, and organizational decision support systems [2]. Sustainable strategic management is an effect of the natural evolution of strategic thinking towards meeting expectations placed by the environment [3]. An ever greater number of organizations have therefore begun to notice that the idea of sustainability is becoming a natural element of their actions and not an issue separated from a strategy being executed [4]. Additionally, as some of the research results prove, it is a factor leading to a reduction in risk accompanying the strategy realization [5]. It results not only in a change in perspective and perception of organizing the strategy implementation process, but also indicates the need for an integration of its aspect [6]. It is described in Figure 1. 


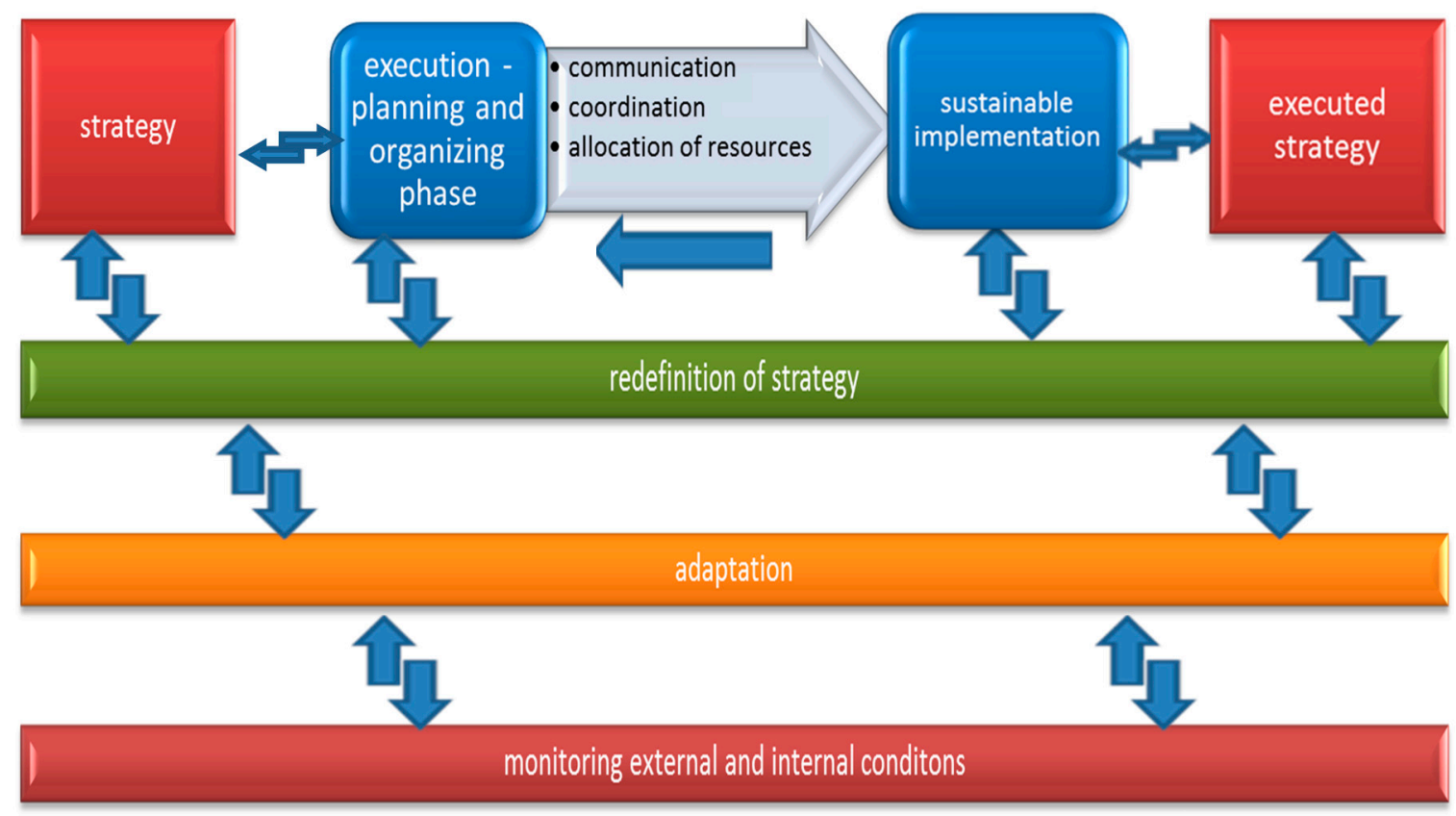

Figure 1. Strategy implementation process (including the sustainability concept). Source: own work based on [7].

Despite application advantages, sustainability is still rarely combined with strategic management [8]. The objective of this work is an examination of the relationships between sustainable strategy implementation and the effectiveness of the strategy execution process. On the basis of the literature, sustainable strategy implementation has been defined using seven perspectives: leadership, strategy, employees, corporate values, resources, tools and processes. The effectiveness of strategy execution, however, comprises both the level to which the strategic aims established are achieved and income dynamics.

As some of the authors indicate, the discipline of strategic management evolves in the direction of a comprehensive and systematic approach, while openness to differentiation and complexity is becoming the domain of those organizations that demonstrate efficacy and consistency in the realization of development concepts devised [9]. It is worth mentioning that the decisions connected with the aspect of sustainability are treated as strategic decisions reflected in the strategy itself as well as in the corporate culture and values [10,11]. In this context, the idea of sustainability, based on continuity, flexibility and comprehensiveness, is becoming of key importance [12]. This comprehensiveness and balance should characterize the perspectives forming a strategy implementation process. Various approaches to their definition may be adopted, beginning with standard elements of the concept of sustainability [6], through an approach derived from the concept of the Balanced Scorecard [13] or Total Quality Management [14], to the use of models depicting key aspects of the strategy execution process [15] or approaches based on them, for instance distinguishing systems, people and programs [16]. For this article, we chose those which combine the approaches mentioned above and form a comprehensive set of elements of a varied nature, which is considered to be a condition for efficacy in the realization of the idea of sustainability [17]. In order to speak of sustainable strategy implementation, it is necessary to accept a strategic approach [18] guaranteeing that the concept of sustainability is an integrated part of a strategic management process [19]. This means that it is essential to incorporate it at three levels-the normative (corporate values, employees, leadership) [20], the strategic (strategy, goals) [21] and the operational (processes, resources, tools) [22].

The first of the perspectives described contains the element naturally associated with sustainability: corporate values. Taking actions which serve the promotion of basic rules and ensuring 
their cohesion with the vision is a complement to a sustainable strategy execution process. It is an integral element combining operational activities with expected results [23]. The literature indicates the existence of a phenomenon described as a "value gap" based on the maladjustment of strategy and the process of its execution to higher values. It becomes crucial then to introduce changes to the process necessary to ensure that activities and expected results remain cohesive [24]. One of the tools assisting with this, and included in this area, is the system of informal communication supporting the comprehension of the vision and strategic goals [25], and at the same time, the integration of the entire strategy execution process [26].

The second perspective is the area of employees, significant because of the necessity, emphasised by many researchers, of paying attention to the nature of the objectives being accomplished by a company and the way in which the results achieved are measured. Aside from financial outcomes, organizational outcomes are mentioned ever more often [27]. These are inseparably linked with the issue of employee engagement in strategies being executed and competitive advantage achieved as a result [28]. Some research indicates that this perspective should be treated as a leading element in strategy implementation as it has a substantial influence on the improvement of company results [29]. It is linked not only with involving employees in work on strategy formulation, but also with the supporting role which they play in achieving long-term goals [30]. Those organizations which obtain good implementation results are able to focus employee attention effectively on tasks connected with strategic goal achievement, which involves assigning decision-making powers as well as establishing clear measures for the appraisal of their effects [31].

The third of the perspectives described is emphasized by a great many authors: leadership as an element linking a strategy, on the one hand, with resources and employees, on the other [32]. The attitudes of managers toward sustainable strategy execution and the perception of particular perspectives of this process directly affect not only its course [33], but also the attitudes of other employees (especially mid-level management) [34]. In order to implement the concept successfully, a change in thinking and attitude is crucial, as these are inseparably linked with leadership [35]. This is also pointed out by [36], who emphasises that the duties of leaders should encompass such tasks as the creation of an aligned mental model, the promotion of individual ownership of the whole, and the cultivation of aligned behaviors.

The fourth perspective, associated with the strategic level, encompasses both strategy and strategic goals. Results of some research indicate that, in many cases, it is not poor execution, but the strategy itself which results in unsatisfactory outcomes [37]. This relates especially to ambiguous definition, a lack of priorities indicated, or a concept of development not adjusted to internal and external determiners [38]. Cocks [39] mentions a vague and blurred strategy among the reasons for failures in implementation, with this often directly linked to a lack of clarity in basic development rules and their coherence with the set of objectives specified [40]. It is indicated in the literature on the subject that the perspective of strategy is closely associated with resources and people and should not be separated from them, but treated holistically as an integral part of a larger whole [41].

Moving on to the operational level, it is worth beginning with the perspective of resources, mainly due to the fact that ensuring sustainability means efficient as well as effective use of available resources with a simultaneous orientation toward strategic objective accomplishment [42]. Moreover, the results of research conducted indicate that resource constraints are a significant and frequently occurring obstacle to strategy execution [43]. Additionally, the question of problems relating to allocation and effective use must be considered [44]. Effectiveness, in this case, does not refer only to an economic aspect, but should also encompass the idea of sustainability, and therefore an allocation of resources which ensures the coherence and integrity of all processes, including the process of strategy realization.

In considering the perspective of strategy execution, it is worth mentioning that the most important role is played by the controlling and implementation of progress measurement systems, which are, at the same time, an element supporting the integration process for all of the perspectives 
described [45]. It is related to the greatest extent to resources and especially to the issue of changes in organizational structure allowing the efficient use of resources possessed [46]. On the other hand, it is necessary to analyze not only the process by which the results of a strategy are measured, since aligning processes and systems to reinforce the desired behaviors and outcomes of equal importance [47]. This therefore relates also to the motivation system, which should be associated with the strategy execution stage [48]. This makes necessary actions aimed at indicating connections between a strategy introduced and other processes within the organization and their design such that they comply with the idea of sustainability.

The last of the perspectives described covers implementation tools. Within the set utilized in the process of strategy execution, Balanced Scorecard displays the greatest integration with the concept of sustainability [49], particularly the non-financial measures [50]. The authors also indicate the use of scheduling and budgeting as well as formal implementation programs, this serving the appropriate allocation of resources and identification of key performance indicators [51]. Measurement may, on the other hand, be supported by strategic controlling [52]. The catalogue of tools is complemented by the strategy map, which may also be considered an element of sustainability due to the fact that it serves the presentation of the manner in which the organization creates value [53] and is able to support other perspectives thanks to its flexibility, operating character, and indication of certain decision-making powers [54].

\section{Experimental Section}

\subsection{Sample and Data Collection, Research Tools}

The group of respondents included managers of 200 corporate headquarters that have been operating for at least five years and are listed among the 500 largest Polish companies in the ranking of Polityka magazine (101 entities) and in the "Forbes Diamonds 2013" ranking (99 companies). The first ranking takes account of sales revenues, the total revenues of the companies, the gross and net profits, as well as the number of employees. The "Diamonds" list included the companies showing the fastest increase in value. The research sample was selected based on the participation in the rankings and thereby achieving market success in the implementation of developed strategies. The obtained results thus could be perceived as an example of good practices, and proposals formulated on this basis could have a universal character. The grounds for undertaking research in the field of strategy implementation were based on the importance of implementation actions and the necessity to ensure consistency between the effects of implementation projects or programs and their operating results. It was especially crucial to identify barriers that hinder the combination of ongoing actions with their strategic implications. The results of the conducted research could be applied, in practice, as a base of knowledge used by the management staff to increase the flexibility and effectiveness of the strategic management process.

The study was conducted using the PAPI (Paper and Pencil Interview) technique; the quantitative survey was carried out with the use of a method based on collecting the data the standardized way. In order to ensure the highest possible representativeness, the sample was selected using the stratified random sampling method. The primary goal of the research was to diagnose the factors that support and hinder the implementation of the strategy. The research tool focused on:

(1) identification of instruments and tools used during the strategy implementation process

(2) defining the procedures and systems supporting strategy execution

(3) analyzing the system for monitoring the effects of strategy implementation

The questions in the questionnaire were of nominal value (the respondents declared the existence of specific issues) and ordinal variable nature (the respondents indicated the strength of their impact on a five-point scale). In order to test the hypotheses, Pearson's correlation coefficient was calculated. 


\subsection{Hypotheses}

As described above, it was assumed that sustainable strategy implementation consists of seven perspectives:

- Leadership (1): the activities of leaders motivating employees effectively; their possession of sufficient knowledge and skills; a clear division of competences, decision-making powers, and responsibility

- Strategy (2): clearly formulated assumptions, internal coherence in development concept (cohesion of vision, objectives, schedule, and budget) and its flexibility (a lack of single-variant solutions adopted in the strategy)

- Employees (3): employee identification with the strategy being executed and acceptance, elimination of internal interest groups hindering strategy execution, employee participation at the strategy formulation phase

- Corporate Values (4): organization of the work of multi-tasking teams, establishment of an efficient informal communication process, provision of coherence between the vision and corporate values

- Resources (5): possession of appropriate financial resources, deployment of the knowledge of employees at various levels, changes in organizational structure allowing effective use of resources possessed

- Tools (6): the use of Balanced Scorecard, strategy maps, strategic controlling and implementation programs as well as budgeting and task scheduling

- Processes (7): a regular measurement of progress in implementation, an incentive system relating employee salary level to the degree to which strategic goals are achieved, a system monitoring the company environment

Effectiveness of strategy execution has been defined by:

- the level of achievement of strategic goals assumed (A): as an indicator of the efficacy of activities performed

- income dynamics (B): as an indicator of the effects of activities performed

In order to accomplish the research objectives assumed, the following hypothesis was formulated:

$H$ : There is a positive interdependency between a sustainable strategy implementation and the effectiveness of its execution.

Auxiliary hypotheses were formulated to verify which of the sustainable strategy implementation areas has the greatest influence on the effectiveness of strategy execution.

H1: Competent leadership affects growth in effectiveness of strategy execution.

H2: Smooth functioning of processes affects growth in effectiveness of strategy execution.

H3: Proper formulation of a strategy affects growth in effectiveness of its execution.

\section{Results and Discussion}

The first stage of the research was the calculation of the average responses to the perspectives of sustainable strategy implementation described above and the degree of effectiveness of strategy execution for each entity surveyed. Table 1 presents the results of the research. 
Table 1. Averages for the sustainability perspectives and degree of effectiveness of strategy execution.

\begin{tabular}{ccc}
\hline Perspective & Mean & SD \\
\hline Leadership & 3.84 & 0.872 \\
Strategy & 3.41 & 0.932 \\
Employees & 3.94 & 0.836 \\
Corporate Values & 2.98 & 0.854 \\
Resources & 3.05 & 0.902 \\
Tools & 3.95 & 0.934 \\
Processes & 3.89 & 0.875 \\
Strategy Execution Effectiveness & 3.75 & 0.869 \\
\hline
\end{tabular}

As the research results show, received values are quite similar. The lowest level was obtained in the case of corporate values, which may indicate that this aspect is emphasized less than the others or the extent of the activities within the organizations surveyed is relatively low. It is certainly connected with their intangible nature and difficult transposition to particular activities of defined measurability (this relating in particular to informal communication along with the coherence of the vision and corporate values).

Further interdependencies between specified perspectives and results obtained (presented in Table 2) were investigated.

Table 2. Correlations between perspectives of sustainable strategy execution.

\begin{tabular}{cccccccc}
\hline Perspective & Leadership & Strategy & Employees & Corporate Values & Resources & Tools & Processes \\
\hline Leadership & 1.00 & 0.763 & 0.854 & 0.553 & 0.638 & 0.558 & 0.785 \\
Strategy & 0.763 & 1.00 & 0.706 & 0.606 & 0.714 & 0.842 & 0.869 \\
Employees & 0.854 & 0.706 & 1.00 & 0.536 & 0.521 & 0.684 & 0.637 \\
Corporate Values & 0.553 & 0.606 & 0.536 & 1.00 & 0.516 & 0.498 & 0.502 \\
Resources & 0.638 & 0.714 & 0.521 & 0.516 & 1.00 & 0.873 & 0.742 \\
Tools & 0.558 & 0.842 & 0.684 & 0.498 & 0.873 & 1.00 & 0.863 \\
Processes & 0.785 & 0.869 & 0.637 & 0.502 & 0.742 & 0.863 & 1.00 \\
\hline
\end{tabular}

The analysis of results obtained once more indicates the lowest level of correlation between corporate values and other perspectives. This is quite a surprising result, as most publications emphasize the role of this area in effective organization management, while the research conducted indicates that this is a rather marginal role compared with other perspectives. The highest results were received in the case of the perspective related to strategy, which demonstrates the importance of the development concept itself and its connection with other areas. This confirms results of research conducted by other authors, indicating that precision, coherence and flexibility of strategy are of great significance in the process of its execution. This interdependency should therefore be highlighted, being a basis for an effective strategy execution process for managers. Relatively high results were also obtained in the case of processes. This also confirms assumptions of other researchers concerning the procedure of the measurement process, motivation and analysis of information flowing from the environment as the elements which contribute to the proper functioning of other areas connected to strategy execution.

The interdependency between a sustainable strategy implementation and the effectiveness of the execution of this process was also examined.

The result obtained (correlation 0.693) allows for the claim that the interdependency between the issues examined is high. This means that the higher the coherence and comprehensiveness of activities, and thus the fuller the provision of a sustainable perspective of the strategy implementation process for the organization, the higher its degree of effectiveness. Those organizations which are aware of the mutual interrelations of particular perspectives obtain better results in activities undertaken and are therefore more effective at achieving strategic goals, which may also translate 
into a growth in income dynamics. The main hypothesis can therefore be accepted. Further analysis of the results, however, indicated certain differences in the interdependencies between particular perspectives, as the results below show (Table 3 ).

Table 3. Correlation between particular perspectives of sustainable strategy implementation and the effectiveness of strategy execution.

\begin{tabular}{cc}
\hline Perspectives & Strategy Execution Effectiveness \\
\hline Leadership & 0.686 \\
Strategy & 0.523 \\
Employees & 0.574 \\
Corporate Values & 0.358 \\
Resources & 0.632 \\
Tools & 0.741 \\
Processes & 0.753 \\
\hline
\end{tabular}

Analyzing the results, it is worth paying attention first to the lowest correlation level in the case of corporate values (0.358), which confirms the earlier observations that this element does not constitute a factor substantially affecting results obtained. Other correlations show at least an average positive level of interdependency, with the highest results received for tools $(0.741)$, processes $(0.753)$ and leadership (0.686). This proves that these perspectives are the most powerful elements improving the results of implementation operations and should be treated as priorities. It is worth mentioning, however, that positive correlations were obtained for all of the perspectives, which may be considered a basis for the indication of certain implications: ensuring a holistic, coherent and sustainable attitude to the strategy execution process has a positive influence on the effectiveness of the results achieved. The sustainable nature of the process may be reached through a concentration not only on issues related to human capital and values, but also on operational matters (organization of processes or tools). Although some of these appear to be of greater importance, all have an impact on the success of the process. All of the hypotheses may therefore be accepted.

\section{Conclusions}

There is no doubt that there is no one universal model of sustainable strategy implementation that can be applied successfully to different types of organizations, as this is closely related not only to the specifics of the company, but also the types or nature of the strategies being executed [55]. This means that it is possible to identify various levels of advancement of activities ensuring a sustainable strategy execution process [56] of a varied level of effectiveness [57]. However, as indicated by a great many results of studies, some of which were mentioned in this article, it is possible to identify the positive influence of the integration of the idea of sustainability with strategy implementation, which is reflected in the effectiveness of activities undertaken.

On the basis of the research, practical implications for executives may also be indicated. The strategy execution process is a complex question which consists of interdependent elements. Accepting a sustainable approach allows for the adoption of a holistic perspective and comprehension of the reciprocal influence of particular aspects and enables a balanced implementation procedure. This paper allows us to understand better what factors should be considered while analyzing the process of strategy execution in order to ensure complex development integrated with organizational goals. Moreover, the findings of the study provide interesting insights for implementing the sustainable approach which might help to improve organizational decision support systems. Those are the reasons identified in this paper that could be mentioned as practical implications connected with the concept of a sustainable strategy execution process.

The main limitation of this study is connected with the subjectivity of the answers provided. Although the group of respondents was chosen among the managers and executives, there is a risk 
that the answers could have been incomplete or did not fully represent the processes and examined issues in a particular organization. The chosen perspectives of sustainability could also be further examined and their number or description could be investigated. Moreover, it is necessary to verify with further study the extent to which the idea of sustainable strategy implementation differs depending on the size of the organization and the branch in which it operates.

Acknowledgments: The project was financed with the funds of The National Science Centre, the project number 2014/13/D/HS4/01425 and DEC-2011/03/B/HS4/04247.

Conflicts of Interest: The author declares no conflict of interest.

\section{References}

1. Cierna, H.; Sujova, E. Parallels between corporate social responsibility and the EFQM excellence model. MM Sci. J. 2015, 10, 670-676. [CrossRef]

2. Hallstedt, S.; Ny, H.; Robert, K.; Broman, G. An approach to assessing sustainability integration in strategic decision systems for product development. J. Clean. Prod. 2010, 18, 703-712. [CrossRef]

3. Stead, J.; Stead, W. The coevolution of sustainable strategic management in the global marketplace. Organ. Environ. 2013, 26, 162-183. [CrossRef]

4. Vencato, C.; Gomes, C.; Scherer, F.; Kneipp, J.; Bichueti, R. Strategic sustainability management and export performance. Manag. Environ. Qual. Int. J. 2014, 25, 431-455. [CrossRef]

5. Yilmaz, A.K.; Flouris, T. Managing corporate sustainability: Risk management process based perspective. Afri. J. Bus. Manag. 2010, 4, 162-171.

6. Talwar, B. Business excellence models and the path ahead. TQM J. 2011, 23, 91-109. [CrossRef]

7. Ignacy, J. Strategy execution model based on research results. In Strategy Implementation in Polish Enterprises; Moszkowicz, K., Ed.; PWN Warsaw: Warsaw, Poland, 2015; p. 193.

8. Kiron, D.; Kruschwitz, N.; Rubel, H.; Reeves, M.; Fuisz-Kehrbach, S.-K. Sustainability's next frontier: Walking the talk on the sustainability issues that matter most. MIT Sloan Manag. Rev. 2013, 12, 3-26.

9. Doz, Y.; Thanheiser, H. Regaining competitiveness: A process of organizational renewal. In Strategic Thinking. Leadership and the Management of Change; Hendry, J., Johnson, G., Newton, J., Wiley, J., Eds.; Wiley: New York, NY, USA, 1993.

10. Stead, J.; Stead, W. Eco-enterprise strategy: Standing for sustainability. J. Bus. Ethics 2000, 24, 313-329. [CrossRef]

11. Jin, B.Z.; Bai, Y. Sustainable development and long-term strategic management. Embedding a long-term strategic management system into medium and long-term planning. World Future Rev. 2011, 3, 49-69. [CrossRef]

12. Szulanski, G.; Kruti, A. Learning to make strategy: Balancing discipline and imagination. Long Range Plan. 2001, 34, 537-556. [CrossRef]

13. Goswami, P.; Banwet, D.; Goswami, K. Sustainable operation management using the balanced score card as a strategic Tool-A research summary. Procedia Soc. Behav. Sci. 2015, 189, 133-143.

14. Gómez Gómez, J.; Martínez Costa, M.; Martínez Lorente, Á. A critical evaluation of the EFQM model. Int. J. Qual. Reliab. Manag. 2011, 28, 484-502. [CrossRef]

15. Higgins, J. The eight 'S's of successful strategy execution. J. Change Manag. 2005, 5, 3-13. [CrossRef]

16. Branzei, O.; Nadkarni, A. The Tata way: Evolving and executing sustainable business strategies. Ivey Bus. J. 2008, 72, 1-5.

17. Lozano, R. A holistic perspective on corporate sustainability drivers. Corp. Soc. Responsib. Environ. Manag. 2015, 22, 32-44. [CrossRef]

18. Galbreath, J. Building corporate social responsibility into strategy. Eur. Bus. Rev. 2009, 21, 109-127. [CrossRef]

19. Engert, S.; Rauter, R.; Baumgartner, R. Exploring the integration of corporate sustainability into strategic management: A literature review. J. Clean. Prod. 2015, in press. [CrossRef]

20. Baumgartner, R. Managing corporate sustainability and CSR: A conceptual framework combining values, strategies and instruments contributing to sustainable development. Corp. Soc. Responsib. Environ. Manag. 2014, 21, 258-271. [CrossRef] 
21. David, F. Strategic Management; Merrill Publishing Company: Columbus, OH, USA, 1989; p. 34.

22. Bonn, I.; Fisher, J. Sustainability: The missing ingredient in strategy. J. Bus. Strat. 2011, 32, 5-14. [CrossRef]

23. Van Marrewijk, M. A value based approach to organization types: Toward a coherent set of stakeholder-oriented management tools. J. Bus. Ethics 2004, 55, 147-158. [CrossRef]

24. Pateman, A. Linking strategy to operations: Six stages to execution. Bus. Perform. Manag. 2008, 12, 10-13.

25. Epstein, M.; Burchard, B. Counting What Counts: Turning Corporate Accountability to Competitive Advantage; Perseus Books: Cambridge, MA, USA, 2000; p. 52.

26. De Sousa Filho, J.M.; Wanderley, L.; Gómez, C.; Farache, F. Strategic corporate social responsibility management for competitive advantage. Braz. Adm. Rev. 2010, 7, 294-309. [CrossRef]

27. Kramar, R. Beyond strategic human resource management: Is sustainable human resource management the next approach? Int. J. Hum. Resour. Manag. 2014, 25, 1069-1089. [CrossRef]

28. Buller, P.; McEvoy, G. Strategy, human resource management and performance: Sharpening line of sight. Hum. Resour. Manag. Rev. 2012, 22, 43-56. [CrossRef]

29. Para-González, L.; Jiménez-Jiménez, D.; Martínez-Lorente, Á. The importance of intellectual capital in the EFQM model of excellence. In Proceedings of the European Conference on Intellectual Capital, Cartagena, Spain, 9-10 April 2015; pp. 253-261.

30. Paraschiv, D.; Nemoianu, E.; Langă, C.; Szabó, T. Eco-innovation, responsible leadership and organizational change for corporate sustainability. Amfiteatru Econ. 2012, 14, 404-419.

31. Henman, L. Turn great strategy into great execution. MWorld Winter 2010, 9, 29.

32. Heras-Saizarbitoria, I.; Marimon, F.; Casadesús, M. An empirical study of the relationships within the categories of the EFQM model. Total Qual. Manag. Bus. Excel. 2012, 6, 1-18. [CrossRef]

33. Baumgartner, R.; Ebner, D. Corporate sustainability strategies: Sustainability profiles and maturity levels. Sustain. Dev. 2010, 18, 76-89. [CrossRef]

34. Harmon, J.; Fairfield, K.; Behson, S. A comparative analysis of organizational sustainability strategy: Antecedents and performance outcomes perceived by U.S. and Non-U.S. based managers. In Proceedings of the International Eastern Academy of Management Conference, Rio de Janeiro, Brazil, 21-25 June 2009.

35. Millar, C.; Hind, P.; Magala, S. Sustainability and the need for change: Organizational change and transformational vision. J. Organ. Chang. Manag. 2012, 25, 489-497. [CrossRef]

36. Haudan, J. Successful strategy execution takes people-Not paper. Employ. Relat. Today 2007, 33, 38-39. [CrossRef]

37. Martin, R. The execution trap. Drawing a line between strategy and execution almost guarantees failure. Harv. Bus. Rev. 2010, 88, 64-71, 168.

38. Sterling, J. Translating strategy into effective implementation: Dispelling the myths and highlighting what works. Strat. Leadersh. 2003, 31, 32-33. [CrossRef]

39. Cocks, G. Emerging concepts for implementing strategy. TQM J. 2010, 22, 262. [CrossRef]

40. Sabourin, V. Through the lenses of strategy execution: Obstacles in engineering management. Leadersh. Manag. Eng. 2012, 12, 54. [CrossRef]

41. Araújo, M.; Sampaio, P. The path to excellence of the Portuguese organisations recognised by the EFQM model. Total Qual. Manag. Bus. Excel. 2014, 25, 427-438. [CrossRef]

42. Siebenhüner, B.; Arnold, M. Organizational learning to manage sustainable development. Bus. Strat. Environ. 2007, 16, 339-353. [CrossRef]

43. How hierarchy can hurt strategy execution. Harv. Bus. Rev. 2010, 7-8, 74-75.

44. Morgan, J. Strategy execution a four-step process. MWorld Winter 2010, 9, 14.

45. Arjaliès, D.-L.; Mundy, J. The use of management control systems to manage CSR strategy: A levers of control perspective. J. Manag. Account. Res. 2013, 24, 284-300. [CrossRef]

46. Hülsmann, M.; Grapp, J. Recursivity and dilemmas of a sustainable strategy management-New visions for a corporate balancing efficiency and sustainability by autonomous co-operation in decision making processes. In Foresight Management in Corporations and Public Organisations-New Visions for Sustainability, Proceedings of the 7th Annual International Conference Foresight Management in Corporations and Public Organisations, Helsinki, Finland, 9-10 June 2005; pp. 1-15.

47. Coon, B.; Wolf, S. The alchemy of strategy execution. Employ. Relat. Today 2005, 32, 29-30. [CrossRef]

48. Hrebiniak, L. Making Strategy Work: Leading Effective Execution and Change; Pearson Education: Upper Saddle River, NJ, USA, 2005. 
49. Figge, F.; Hahn, T.; Schaltegger, S.; Wagner, M. The sustainability balanced scorecard-Linking sustainability management to business strategy. Bus. Strat. Env. 2002, 11, 268-284. [CrossRef]

50. Nathan, M. 'Lighting tomorrow with today': Towards a (strategic) sustainability revolution. Int. J. Sustain. Strat. Manag. 2010, 2, 29-40. [CrossRef]

51. Saunders, M.; Mann, R. Implementing strategic initiatives: A framework of leading practices. Int. J. Oper. Prod. Manag. 2008, 28, 1104-1106. [CrossRef]

52. Ramsey, R. Strategic management: Formulation, implementation, and control in a dynamic environment. Int. J. Commer. Manag. 2010, 20, 188-189. [CrossRef]

53. Kaplan, R.; Norton, D. The strategy map: Guide to aligning intangible assets. Strat. Leadersh. 2004, 32, 10-17. [CrossRef]

54. Free, C.; Qu, S. The use of graphics in promoting management ideas: An analysis of the balanced scorecard, 1992-2010. J. Account. Organ. Chang. 2011, 7, 158-189. [CrossRef]

55. Lee, M.-D. Configuration of external influences: The combined effects of institutions and stakeholders on corporate social responsibility strategies. J. Bus. Ethics 2011, 102, 281-298. [CrossRef]

56. Van Marrewijk, M.; Werre, M. Multiple levels of corporate sustainability. J. Bus. Ethics 2003, 44, 107-119. [CrossRef]

57. White, P. Building a sustainability strategy into the business. Corp. Gov. Int. J. Bus. Soc. 2009, 9, 386-394.

(C) 2015 by the author; licensee MDPI, Basel, Switzerland. This article is an open access article distributed under the terms and conditions of the Creative Commons by Attribution (CC-BY) license (http://creativecommons.org/licenses/by/4.0/). 